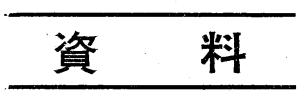

\title{
ネス゚ミの交替反応現象 II
}

一一作業量の影響（続き）—

一一東京教育大学 藤 田統一

T型迷路のよ5飞左右対称の装置を用い, 耐方の目標 箱に餌を置いていずれの方向を選んでも必ず強化される よらにする。そのような条件の下で，ネズミに連続して 左右いずれか一方の方向を自由飞選択させると, ネズミ 山直前試行で反応した方向を澼けて反応する傾向を示 す。これがいわゆる菼替反応 (alternation response) である $(1,4) 。$

筆者はこの現象に関していくつかの実験を行い, 若干 の法則性のあることを見出したが，その中の一つに交替 反応と作業量の関係を迫求する実験がある $(5,6)$ 。交替反 応が作業量の増加飞伴い増加するか否かの間題は近年論 争を起し $(2,4) ， 2 つ の$ 否定的な実験紹果が 報告されて いるが $(2,3)$ ，筆者はこれらの実験で採用された作策量 増加方法飞疑問を持ち, $\mathrm{T}$ 型迷路の腕部通路を趜長及び 傾斜させる方法を用いてみた。その結果，かかる作箘量 増加は交替反応を增加せしめることが分つた。これは前 記二者の絓果に反する事実であるが，嚴密にいえば，作 筹量吕腕部通路の延長から傾斜へと非連続に増加してい る久点があつた。

したがつて，以下の実験では傾斜度のみが巽なる二群 の变替反応現象を比較し，さらにその条件を実験途上に て交互に奕換した際の影響を検討してみた。

\section{方 法}

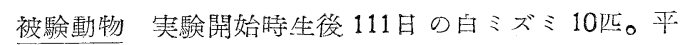
均体重 $137.8 \mathrm{~g}$ 。 ボて雄。ナイーヴ。

装 置 通常の型より腕部通路の長い下型迷路を用い る。出発箱出口より選択点まで $50 \mathrm{~cm}$, 選択点より目標 箱入口未で $106.5 \mathrm{~cm}$ である。腕部通路は選択点より目標 箱へかけて $2^{\circ} \sim 10^{\circ}$ の傾斜 (上り坂) をつけることが出 来る。

手続き亳験開始一週間前より取扳いにならし，同時 『1 日 1 回体重の $5 \%$ 慨を与兄て, 約 24 時間の慨餓動 因沉順応せしめる。

第1日。5 匹づつ一諸《装置内を30分間探索させる。 第 2 日。1 匹づつ 5 分間探索させる。

第3 日。(予備訓練) 選択点の一方のドアーを下さこ
をにより, 左右へ各10回, 計20可の強制強化訓練を行う。 その序列はランダムで交替率* 50\%のものを用いる。そ の際腕部通路の傾斜度は, $1 \sim 5$ 試行が $2^{\circ}$ 。6 10試行 が10。 $。 11 〜 15$ 試行が $2^{\circ}$ 。16 20試行が $10^{\circ}$ と変化する。 武行間隔は20秒である。

第 4 日 2 日。(実験前期) 予備訓練の走行特間执よ び体重により, 被験動物をほぼ等しい 2 群に分ける。以 後 5 日間, 管I群には両腕部の傾斜度 $10^{\circ}$ 。第II群飞は $2^{\circ}$ の装置を用いる。1 匹 1 日連続 11 自由選択試行の単 位を 5 分の休㥳時間をはさんで 2 回。計 2 単位 22 武行行 5。これを5日間続ける(単位 $1 \sim 10$ )。雨目標箱に慨 が置かれているから，動物が選択点で左右いずれの方向 を選択しても必ず強化試行となる。試行間隔は20秒。每 試行, 選択方向, 前試行と交替の有無, 走行時間を記録 する。

第9日〜13日。(実験後期) 第9日《雨群の傾斜度を交

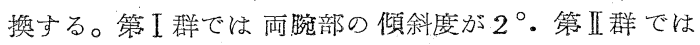
10○となる。その他の手続きに変化なく，これを5日間 続ける(単位11〜20)。

\section{結果と考察}

実験前後期各単位飞和ける両群の交替区応数 (1 単位 の茭替反応可能数は50である)を Table 1 K，それを交 替率で表わしたものをFig. 1 亿示す。

実験前期 Fig.1 亿見られるように, 第I群の艾替率

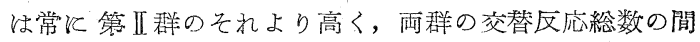
には 1\%以下の危険率で有意差が認められる。これは腕 部通路の傾斜度が大となると、すなわち選択後の反応に 要する作等量が増大すると, 交替反応の頻度が增加する ことを示すもので, 先に発表した筆者の結果 (6) と一致す る。また第】群の交替率は実験経過に伴う変動が少く 比輍的安定しているが, 筹II群では学位による增減が

*坴替率とは，效替反応発生の度合を示すもので，実 際生じた交替反応数の艾替反応可能数に対する割合の ことである。必ず左右に艾替した場合は 100\%，常に一 方向のみ飞反応飞た場合は $0 \%$ ，偶然に反応が生ずる場 合は $50 \%$ となる。 
見られる。しかしこれに特定の傾向があるとは思えない。 実験後期 両群の作業量条件は単位 11 より交換された が，交換值後にはその影響が明らかとはいえない。単位 11 の第 I 群の交替反応数は 前期の艾替反応総数飞比べて 減少したとい方るが ( $5 \%$ 年有意水準で), 単位12ではも とに回復している。またこの間の第II群の菼替反応数は 交換前之差がない。しかし, 単位13以後は条件交換の影 響が次第に顕著となり, その後の第 I群の各単位での交 替反応数は前期と $1 \%$ 以下の危険率で有意差がある。こ れにより交換による作墓量の減少が㝔替反応数を減少せ
響を一応純粋に表わしているものと考えるならば，条件 㝔換の方向的差異の影響を検討する為には，条件交換後 の各群の交替反応総数を, 前期の同条件群（実際には他 の群)が前期で示した交替反応数と比較してみればよ い。Table 2 がそれである。これによると, 条件交換後 の作業量（大）群の交替反応数と交換前の作業量（大） 群の交替反応数との間には 有意差が認められないが, 条

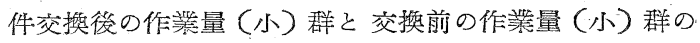
閒には有意差があり，交換後の方が交替反応数が少りこ とがわかる。このことは, 条件交換の影響が少い単位11,

Table 1 各单位に和ける交替反応数

\begin{tabular}{|c|c|c|c|c|c|c|c|c|c|c|c|c|c|c|c|c|c|c|c|c|c|c|}
\hline \multirow[b]{2}{*}{ 単位 } & \multicolumn{11}{|c|}{ 実験前期 } & \multicolumn{11}{|c|}{ 実 験 後 期 } \\
\hline & 1 & 2 & 3 & 4 & 5 & 6 & 7 & 8 & 9 & 10 & 計 & 11 & 12 & 13 & 14 & 15 & 16 & 17 & 18 & 19 & 20 & 阡 \\
\hline 第 I群 & 34 & 31 & 35 & 33 & 32 & 36 & 34 & 36 & 35 & 34 & 340 & 26 & 36 & 18 & 17 & 23 & 20 & 19 & 5 & 18 & 16 & 198 \\
\hline 第II群 & 23 & 21 & 27 & 29 & 24 & 21 & 17 & 21 & 23 & 26 & 232 & 25 & 24 & 31 & 33 & 33 & 36 & 34 & 39 & 36 & 37 & 328 \\
\hline 差 & 11 & 10 & 8 & 4 & 8 & 15 & 17 & 15 & 12 & 8 & 108 & 1 & 12 & -13 & $-16-$ & -10 & -16 & -15 & $|-34|$ & -18 & -21 & -130 \\
\hline$x^{2}$ & 4.94 & 4.01 & 2.72 & 0.69 & 2.58 & 9.181 & $11.589^{9}$ & 9.18 & 4.77 & 2.62 & 47.63 & 0.04 & 6.006 & 6.761 & 10.244 & 4.061 & 10.399 & 9.03 & 46.92 & 13.041 & 17.70 & 67.78 \\
\hline $\mathrm{P}$ & $*$ & $*$ & & & & $* *$ & $* *$ & $* *$ & * & & $* *$ & & $*$ & $* *$ & $* *$ & $*$ & $* *$ & $* *$ & $* *$ & $* *$ & $* *$ & $* *$ \\
\hline & $\begin{array}{l}* 5 \\
* * 1\end{array}$ & $\begin{array}{l}\% \text { 以 } \\
\% \text { }\end{array}$ & 下o & קוd & 率で有 & $\begin{array}{l}\text { 有意 } \\
\text { 意 }\end{array}$ & & & & & & & & & & & & & & & & \\
\hline
\end{tabular}

Table 2

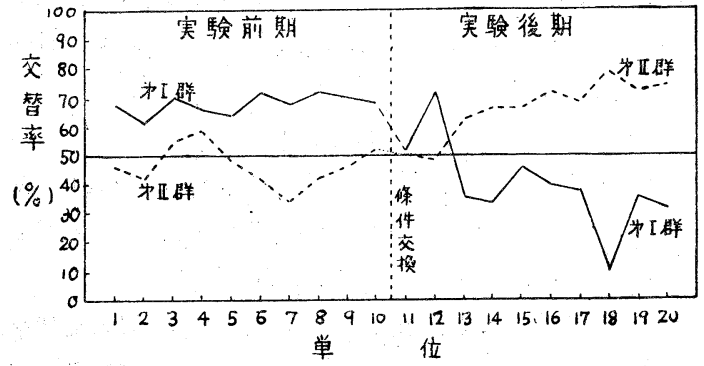

Fig. 1

しめたことがわかる。また第群でもこの間は前期と有 意差があり, 作業量の増加が 交替反応数を増加せしめた といえる。さらに, 実験後期の両群の交替反応総数の間 には $1 \%$ 以下の危険率で有意差があり, 作業量と交替率 の関你は実験前期と一致する。

しかし，雨群の作業量交換による影響を比較してみる と，Fig. 1を一見してわかるよう飞，第群の方が，す なわち作業量大 小变化した場合の方が，その逆作 業量小 $\rightarrow$ 大変化した場合よりも交替反応の変動が著し い。実験前期の両群の荾替反応数が，各作業量条件の影

\begin{tabular}{|c|c|c|c|c|c|c|}
\hline 作荳量 & $\begin{array}{l}\text { 害験 } \\
\text { 前期 }\end{array}$ & $\begin{array}{l}\text { 泰験 } \\
\text { 期 }\end{array}$ & 差 & $\chi^{2}$ & $\mathrm{df}$ & $\mathrm{P}$ \\
\hline 天 & 340 & 328 & 12 & 0.65 & 1 & $0.30<\mathrm{P}<0.50$ \\
\hline 小 & 232 & 198 & 34 & 4.72 & 1 & $0.02<\mathrm{P}<0.05$ \\
\hline
\end{tabular}

12 の交替反応数を除いて計算するとさらに明白となる。

何故にこのよ が異なつてくるかは明らかでないが，少くとも，条件交 換後の変替反応が交㨘前の条件によらて形成された何え らかの機制によつて影響を受けていること，招よび 交替 反応発生の機制には現在考克られているるのより複雑な ものが含まれていることを暗示している。したがつて， 今後の研究に打いて交替反応之作策量の関係を道求する

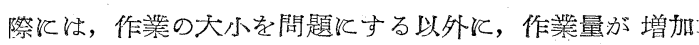
又は減少する際の変化方向をも教慮することが必要であ 万5。

以上にのべたごとく，この実験に扮いても作策量は交 替反応影響を改ぼす要因であること，和よび交替反応 の頻度は作率量の増大に伴つて増加することが明らかに。 
なつた。それゆえ，かつて等者が指摘したように(6), 交替反応と作笪量の刘応関係を否定した Montgomery 達の二実験には, 作業量增加方法に不薉な点があつたの ではないかと思われる。

\section{結果の要約}

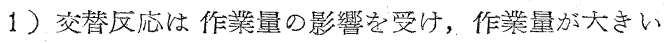
程交替率が高い。

2）作端量条件が变化した後しばらくは，前条件の影 響が残る。

3）その後は新しい作業量条件の影響が強くなり, 作 業量が大きい程交替率が高い。

4) 作業量变化の方向によりその影響が異なる。作業 量大 $\rightarrow$ 小之変化した場合の方が, その逆の場合より条件 变化の影響を強く受ける。

(以上の実験は昭和 28 年 8 月, 東亲教育大学板橋分室 比較心理学研究室にて行われたものである。?

\section{交 献}

1) Glanzer, M. : Stimulus Satiation : An Explanation of Spontaneous Alternation and Related Phenomena.Psychol.Rev. 1953, 60, 257-268.

2) Montgomery, K.C. : "Spontaneous Alterna- tion" as a function of Time between Trials and Amount of Work. J.exp. Psychol.1951, $42,82-93$

3) Riley, D.A.and Shapiro, A.M: : Alternation Behavior as a Fuction of Effortfulness of Task and Distribution of Trials. J.com. physiol. Psychol. 1952, 45, 478-475.

4) Solomon, R.L. . The Influence of Work on Behavior Psychol. Bull.1948, 45, 1-40.

5) 藤田 統: 反復反応回避々 Hull の学習理論, 昭 和27年度, 東京教育大学卒鄴論文 (未発表).

6) 藤田 統: ネズミの交替反応現俰, I 試行闍隔・ 作䠞量・飢餓動因の影響, 心理学研究, 管 25 巻, 第4 号230-239 (1955). - 1955. 5. 20 受稿 -

\section{外傷性神経症のロールシャツハ反応}

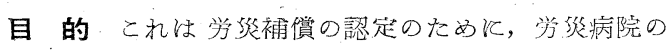
外来を訪れる，災害患者化関する報告であるが，彼等の

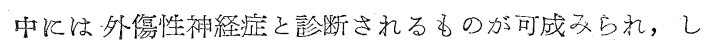
か子, 七ステリ一反応之みられるものが多いことから, そのパーソナリティを知るととの必要が生じて来ている のである。このために, 先づロールシャツハ・テストを 用いて，その性格特徵の一端をとら光ようとしたのであ る。

外傷性神経症 Traumatic Neurosis といらのほ, 精神分 析学者たと光ば D・フェニケルによれば，心的な外傷体 験にもとづく神経症のことを指しているが，これは特殊 な用語であつて, 一般の精神医学では, 肉体的な外傷の 後に起つてくる神経症のことを云つている。たと光ば三 宅鉱一膊士は，乙れを「頭部外傷時のみに限らず他部身 体災害飞も続発する心因精神異常なり」と云つている 加，要するに外稘をきつかけにして起つてくる神経症を 総じて, 外傷性神経症と云うのである。勿論, 肉体的飞外 傷を受けることが同時に心理的な外傷体験となるとも云 えるし，所謂年金神経症的なるのもこの中に舍んでくる ので，この這断名はあくまで便管的なものである。

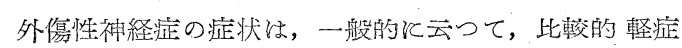
の場合飞は, 易怒性, 過度の発汗, めまい, むからき, チックなどであり, 重症の場合には, 言語障碍, 歩行障、

\section{一東京大学 片，口安 史一}

碍，ケイレン、マヒなどである。この外，頭痛，心悸，

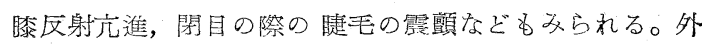

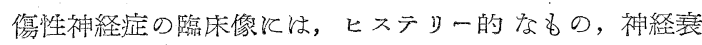
弱的なもの，不安神経症的なものなどがある。

(1) 被験者 昭和28年10月から，昭和30年2月末で の間飞東京学災病院の外来飞来院した災害患者の中，外 科医によつて「神経症的」とみられ，さらに精神科医に よつて「外傷性神経症」と誩断されたもの約 200名に一 応テストを施したが，ここで使用するデータは，その中 何らの疑いもなしに「外傷性神経症」と彭断されたもの 55名のプロトコルである。

この55名の Vp. は高小來或はそれ以下のもの30名で

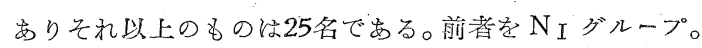
後者を NII グループと名づける。 $N_{I}$ 群は, 主として日

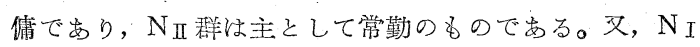
群は，ヒステリー区応と目されるものが多く、N $\mathrm{II}$ 群に は神経㐮弱的な子のが多い。

(2) 方 法 用いたテストは, 口ールシャッハのオリ デナル・カードであり, 施行法はクロツパーの方法に主 として依存している。

整理法は，パーリナリティー・リデデイティを測定す ることに主眼を置き，リヂデイテイ・インデックス従 つた。 